\title{
Reducing Students' Agitation in the University Through Students' Participation in Decision-making and Implementation of Their Welfare Matters.
}

\author{
F.U. Okorie \\ Department of Science Education, Michael Okpara University of Agriculture, Umudike PMB 7267, Umuahia, \\ Abia State Nigeria.
}

\begin{abstract}
The issue of students' welfare is a stabilizing factor in the attainment of academic goal achievement and rancor-free atmosphere in the Universities in South Eastern States of Nigeria. This paper highlights the possible areas of students' involvement in decision-making concerning their welfare. The study is predicated on reliability result of Pearson Product Moment Correlation Coefficient determined from a pilot test of questionnaire items administered to Principal Officers and Students' Union Executives of University of Uyo. The main study using frequency counts and percentages of pooled responses comprising of 36 principal officers and 88 students union executives from nine universities yielded chi-square values of 27.40 and 137.19 respectively, as compared to critical chi-square value of 13.6 for 8 degrees of freedom at 0.05 level of significance. Thus, the result affirms the need for students' participation in decision-making and implementation in their welfare matters. Identified areas of students' participation include accommodation, transportation, feeding, sporting activities and health services as detailed in the subsequent sections of this paper.
\end{abstract}

Keywords: Welfare matters, students' participation, chi-square values, decision-making and implementation.

\section{Introduction}

The current global trend in educational institutions, especially in developed countries, is the involvement of students as stake holders in decision-making and implementation of affairs which they are subject to, in order to facilitate goal achievement. (Dimitri 2005; Nadeem 2008; Uyanga 1989; Washburn and Hammand 1982). Many researchers have arrived at the same conclusion regarding the positive effect of students' participation in decision-making and goal achievement in their various Universities. (Okumbe 1998; Hill and Jones 1995; Ukeje et al 1992; Babalola and Adedeji 2003; Oni 1997; Akomolafe and Ibijola 2011; Adeniyi 2000).

Leaders in higher institutions who adopt Likert (1997) managerial system of participative decisionmaking reap the benefits of trust, loyalty, commitment, warmth and friendliness from both students and staff, thereby ensuring high performance in goal achievement. This study investigates the perception of Students' Union Executives and Principal Officers in nine Universities in South Eastern States of Nigeria on students' participation in decision-making on welfare matters of their students.

\section{Design of Study}

\section{Research Method}

The design of the study is a descriptive survey in which data collection involves a target population from nine Universities. This design is considered appropriate because the events being studied have already taken place. That means the students' involvement or non- involvement in decision-making in those Institutions is an already existing situation.

\section{Area of Study}

The study was carried out in nine Universities in the South Eastern States of Nigeria comprising of Abia, Imo, Anambara, Enugu and Ebonyi states.

\section{Population of Study}

The population of study consists of all 138 Principal Officers and Students' Union Executives of the nine Universities in the South Eastern part of Nigeria. This is made up of 49 Principal Officers and 89 
Table 1: Population of study

\begin{tabular}{|c|c|c|c|c|c|c|c|c|c|}
\hline S/No. & State & $\begin{array}{l}\text { Federal } \\
\text { Universities }\end{array}$ & 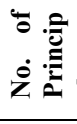 & 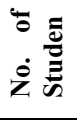 & Total & $\begin{array}{l}\text { State } \\
\text { Universities }\end{array}$ & 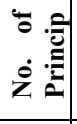 & ¿ & Total \\
\hline 1. & Abia & $\begin{array}{l}\text { Michael Okpara } \\
\text { University of } \\
\text { Agriculture } \\
\text { Umudike } \\
\end{array}$ & 5 & 9 & 14 & $\begin{array}{l}\text { Abia State } \\
\text { University, } \\
\text { Uturu }\end{array}$ & 6 & 10 & 16 \\
\hline 2. & Anambra & $\begin{array}{l}\text { Nnamdi Azikiwe } \\
\text { University Awka }\end{array}$ & 6 & 9 & 15 & $\begin{array}{lr}\text { Anambra } & \text { State } \\
\text { University } & \text { of } \\
\text { Science } & \text { and } \\
\text { Technology, Uli }\end{array}$ & 5 & 10 & 15 \\
\hline 3. & Ebonyi & - & - & - & - & $\begin{array}{l}\text { Ebonyi State } \\
\text { University, } \\
\text { Abakaliki }\end{array}$ & 5 & 11 & 16 \\
\hline 4. & Enugu & $\begin{array}{l}\text { University of } \\
\text { Nigeria Nsukka }\end{array}$ & 6 & 9 & 15 & $\begin{array}{l}\text { Enugu State } \\
\text { University of } \\
\text { Technology, } \\
\text { Enugu }\end{array}$ & 5 & 10 & 15 \\
\hline 5. & Imo & $\begin{array}{l}\text { Federal } \\
\text { University of } \\
\text { Technology, } \\
\text { Owerri } \\
\end{array}$ & 6 & 10 & 16 & $\begin{array}{l}\text { Imo State } \\
\text { University, } \\
\text { Owerri }\end{array}$ & 5 & 11 & 16 \\
\hline Total & 5 & 4 & 23 & 37 & 60 & 5 & 26 & 52 & 78 \\
\hline
\end{tabular}

Source: Data collected from the Institutions

Students' Union Executives in both State and Federal Universities in South Eastern States of Nigeria The distribution of the target population and the Universities involved are shown in Table 1 above.

\section{Sample and Sampling techniques}

A purposive sampling technique was used consisting of the entire 138 Principal Officers and Students' Union Executives of the nine Universities in the South Eastern States of Nigeria. The choice of using the entire population is informed by the population being relatively small.

\section{Instrument of data collection}

The instrument of data collection was a researcher-made questionnaire called students' participation in decision-making and goal achievement questionnaire (SPIDAQAQ) used for two groups of respondentsPrincipal Officers and Students' Union Executives. The questionnaire was divided into two sections A and B.

Section A focused on bio-data comprising of name of institution, proprietorship of the institution and status of the respondent. Section B focused on students' participation in decision -making with participation in welfare matters as a subset.

The response to the statements were a modified four-point Lickert (1997) scale of Strongly Agree (SA) $=4$ points, Agree $(A)=3$ points, Disagree $(D)=2$ points and Strongly Disagree $(S D)=1$ point. All responses under Strongly Agree and Agree were collated and taken as "Agree" while responses under Disagree and Strongly Disagree were collated and taken as "Disagree".

\section{Validation of the Instrument}

The face and content validity were determined by giving the questionnaire items to experts in measurements and evaluation. Their inputs were requested in checking the relevance, correctness and any ambiguity of items to ensure that the questionnaire items elicited the required responses. Their contributions were used to review and modify the questionnaire items, resulting in 9 items on students' participation in welfare matters.

\section{Reliability of Instrument}

To ascertain the reliability of the instrument, the validated items were subjected to a pilot test. This was done by administering the instrument on a total of 15 Students' Union Executives and 6 Principal Officers of University of Uyo, Akwa Ibom State, as they were not part of the main study.

A test-retest method of two weeks interval was used to determine the reliability of the questionnaire items over time. The scores from the two tests were analyzed using Pearson Product Moment Correlation Coefficient Statistic. This yielded a reliability coefficient of 0.64 which was considered adequate for the study. 


\section{Administration of the Instrument}

The questionnaires for the Principal Officers were personally administered by the researcher while those of the Students' Union Executives were administered by 9 research assistants who were properly briefed on how it should be done. They also assisted in the retrieval. The administration and retrieval of the questionnaires were accomplished within one month with about $90 \%$ return rate.

\section{Results and Discussion}

Tables 2 (a) and (b) contain the responses of both the Principal Officers and Students' Union Executives on 9 questionnaire items regarding students' participation in decision-making on their welfare matters. Except for items 8 and 9 concerning hostel management and allocation of bed spaces in which both groups of respondents of Principal Officers and Students' Union Executives show more disagreement on students' participation, the two groups of respondents are very much in agreement on students' participation in the first 7 items of the questionnaire. These include provision of health services, provision of electricity, transportation of students on the campus, provision of portable water, provision of recreational facilities, allocation of canteen to food vendors and allocation of business centres.

These agreements translate to a total of $64.7 \%$ for Principal Officers and $56.3 \%$ for

Table 2: Perceptions of Principal Officers and Students' Union Executives on Students' Participation in Decision-Making on Students' Welfare Matters and Goal Achievement.

\begin{tabular}{|c|c|c|c|c|c|c|c|}
\hline \multirow{3}{*}{$\mathbf{S} / \mathbf{N}$} & \multicolumn{7}{|c|}{$\begin{array}{ll}\text { Table 2a } & \text { Principal Officers } \\
\end{array}$} \\
\hline & \multirow[t]{2}{*}{ Questionnaire Items } & \multicolumn{2}{|c|}{ Agree } & \multicolumn{2}{|c|}{ Disagree } & \multicolumn{2}{|c|}{ Total } \\
\hline & & No & $\%$ & No & $\%$ & No & $\%$ \\
\hline 1 & Provision of health services & 27 & 75 & 9 & 25 & 36 & 100 \\
\hline 2 & Provision of electricity & 28 & 77.8 & 8 & 22.2 & 36 & 100 \\
\hline 3 & $\begin{array}{l}\text { Transportation of students in the } \\
\text { campus }\end{array}$ & 25 & 69.4 & 11 & 30.6 & 36 & 100 \\
\hline 4 & Provision of portable water & 18 & 50 & 18 & 50 & 36 & 100 \\
\hline 5 & Provision of recreational facilities & 29 & 80.6 & 7 & 19.4 & 36 & 100 \\
\hline 6 & $\begin{array}{l}\text { Allocation of canteens to food } \\
\text { vendors }\end{array}$ & 25 & 69.4 & 11 & 30.6 & 36 & 100 \\
\hline 7 & Allocation of business centres & 25 & 69.4 & 11 & 30.6 & 36 & 100 \\
\hline 8 & Management of hostels & 16 & 44.4 & 20 & 55.6 & 36 & 100 \\
\hline 9 & $\begin{array}{l}\text { Allocation of rooms and bed } \\
\text { spaces }\end{array}$ & 15 & 41.7 & 21 & 58.3 & 36 & 100 \\
\hline & Total & 208 & 64.2 & 116 & 35.8 & 324 & 100 \\
\hline
\end{tabular}

\begin{tabular}{|c|c|c|c|c|c|c|c|}
\hline \multirow{3}{*}{$\mathbf{S} / \mathbf{N}$} & \multirow{3}{*}{$\begin{array}{l}\text { Table 2b } \\
\text { Questionnaire Items }\end{array}$} & \multicolumn{6}{|c|}{ Students' Union Executive } \\
\hline & & \multicolumn{2}{|c|}{ Agree } & \multicolumn{2}{|c|}{ Disagree } & \multicolumn{2}{|c|}{ Total } \\
\hline & & No & $\%$ & No & $\%$ & No & $\%$ \\
\hline 1 & Provision of health services & 51 & 58 & 37 & 42 & 88 & 100 \\
\hline 2 & Provision of electricity & 50 & 56.8 & 38 & 43.2 & 88 & 100 \\
\hline 3 & $\begin{array}{l}\text { Transportation of students in the } \\
\text { campus }\end{array}$ & 77 & 87.5 & 11 & 12.5 & 88 & 100 \\
\hline 4 & Provision of portable water & 55 & 62.5 & 33 & 37.5 & 88 & 100 \\
\hline 5 & $\begin{array}{l}\text { Provision of recreational } \\
\text { facilities }\end{array}$ & 60 & 68.2 & 28 & 31.8 & 88 & 100 \\
\hline 6 & $\begin{array}{l}\text { Allocation of canteens to food } \\
\text { vendors }\end{array}$ & 58 & 65.9 & 30 & 34.1 & 88 & 100 \\
\hline 7 & Allocation of business centres & 58 & 65.9 & 30 & 34.1 & 88 & 100 \\
\hline 8 & Management of hostels & 20 & 22.7 & 68 & 77.3 & 88 & 100 \\
\hline \multirow[t]{2}{*}{9} & $\begin{array}{l}\text { Allocation of rooms and bed } \\
\text { spaces }\end{array}$ & 17 & 19.3 & 71 & 80.7 & 88 & 100 \\
\hline & Total & 446 & 56.3 & 346 & 43.7 & 792 & 100 \\
\hline
\end{tabular}




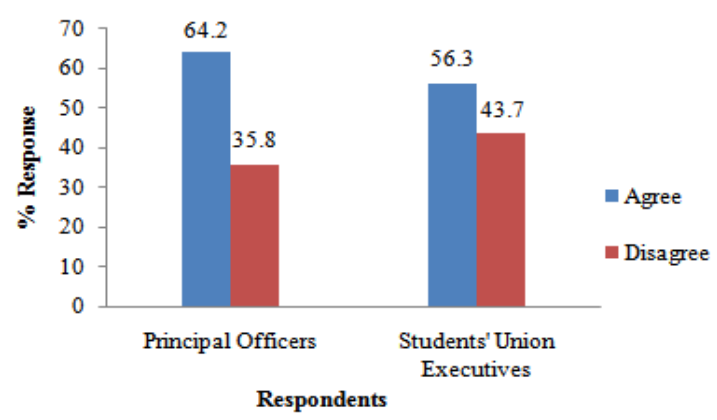

Fig. 1: Perceptions of Principal Officers and Students' Union Executives on Students' Participation in DecisionMaking on Students' Welfare Matters and Goal Achievement

Students' Union Executives while $35.5 \%$ of Principal Officers and $43.7 \%$ of Students' Union Executives are in disagreement of students' participation. The results are displayed in the bar chart of Fig. 1. Table 3 shows the chi-square analysis and values obtained for both Principal Officers and Students' Union Executives. Evidently, the chi-square values of 27.40 for Principal Officers and 137.19 for Students' Union Executives are in high contrast with the smaller critical chi-square value of 13.36 for 8 degrees of freedom at 0.0 .5 level of significance.

Table 3: Chi-square Analysis of the Responses of Principal Officers and Students' Union Executives on Students' Participation in Decision-making on Students' Welfare Matters and Goal Achievement.

\begin{tabular}{|c|c|c|c|}
\hline \multicolumn{4}{|l|}{ Item } \\
\hline Principal Officers & Agree & Disagree & Total \\
\hline $\begin{array}{l}\text { Students' participation in Decision-making on provision of } \\
\text { health services }\end{array}$ & $27(23.11)$ & $9(12.89)$ & 36 \\
\hline Provision of electricity & $28(23.11)$ & $8(12.89)$ & 36 \\
\hline Transportation of students in the campus & $25(23.1)$ & $11(12.89)$ & 36 \\
\hline Provision of portable water & $18(23.11)$ & $18(12.89)$ & 36 \\
\hline Provision of recreational facilities & $29(23.11)$ & $7(12.89)$ & 36 \\
\hline Allocation of canteens to food vendors & $25(23.11)$ & $11(12.89)$ & 36 \\
\hline Allocation of business centres & $25(23.11)$ & $11(12.89)$ & 36 \\
\hline Management of hostels & $16(23.11)$ & $20(12.89)$ & 36 \\
\hline Allocation of rooms and bed spaces & $15(23.11)$ & $21(12.89)$ & 36 \\
\hline Sub-total & 208 & 116 & 324 \\
\hline \multicolumn{4}{|l|}{ Students' Union Executives } \\
\hline $\begin{array}{l}\text { Students' participation in decision-making on provision of } \\
\text { health services }\end{array}$ & $51(49.56)$ & $37(38.44)$ & 88 \\
\hline Provision of electricity & $50(49.56)$ & $38(38.44)$ & 88 \\
\hline Transportation of students in the campus & $77(49.56)$ & $11(38.44)$ & 88 \\
\hline Provision of portable water & $55(49.56)$ & $33(38.44)$ & 88 \\
\hline Provision of recreational facilities & $60(49.56)$ & $28(38.44)$ & 88 \\
\hline Allocation of canteens to food vendors & $58(49.56)$ & $30(38.44)$ & 88 \\
\hline Allocation of business centers & $58(49.56)$ & $30(38.44)$ & 88 \\
\hline Management of hostels & $20(49.56)$ & $68(38.44)$ & 88 \\
\hline Allocation of rooms and bed spaces & $17(49.56)$ & $71(38.44)$ & 88 \\
\hline Sub-total & 446 & 346 & 792 \\
\hline $\begin{array}{l}\text { cipal Officers } \\
\text { Cal }=27.40 \\
\text { sitical }=13.36 \\
=8, \dot{\alpha}=0.05\end{array}$ & Studen & $\begin{array}{l}\text { Executives } \\
=137.1 \\
\text { cal }=13.36 \\
\dot{\alpha}=0.05\end{array}$ & \\
\hline
\end{tabular}

\section{Conclusion}

The perception of Principal Officers and Students' Union Executives on students' participation in their welfare matters in nine Universities in the South Eastern States of Nigeria has been successfully investigated and analyzed. The results show overwhelming agreement by both groups of respondents consisting of Principal Officers and Students' Union Executives on the need to involve students in nearly all aspects of welfare matters affecting them.

Urgent creation of awareness and implementation of these results are highly recommended as this will go a long way in reducing students' unrest. 


\section{References}

[1]. Adeniyi, E. O (2000). Participatory Management, Job Satisfaction and Commitment Among Sec, School Teachers in Ogun State Nigeria (Unpublished PhD. Thesis) University of Ibadan.

[2]. Akomolofe, C. O and E. Y. Ibijola (2011) Students' Participation in University Governance and Organizational Effectiveness in Ekiti and Ondo States, Nigeria. Retrieved from ScienceHub, http://www.scihub.org/AJSMS on 11/8/2011.

[3]. Babalola, J. B., S. O Adedeje, (2003) eds Contemporary Issues in Education Management. A Book of Honour, Ibadan: Department of Educational Management, University of Ibadan.

[4]. Dimitri, T (2005) Students participation in University Administration View Public Profile, Visit Dimitri Terryn's Home page 06.03.05,071, Retrieved on 8/12/2008.

[5]. Hill, C. W. L and R. G. Jones (1995) Strategic Management Theory. An Integrated Approach. USA: Houghton Miffin Company.

[6]. Likert, R (1971) New Patterns of Management. Koga Kusha, McGraw-Hill Ltd.

[7]. Nadeem, A. M (2008) Decision-Making Practices in Universities of Pakistan. Journal of Diversity Management- Fourth Quarter, University of Sargodha, Pakistan. Retrieved from www.se.hec.gov.pk/saphds/submit.asp?supid=386-241 on 6/09/2010.

[8]. Okumbe, J. A (1998), Educational Management Theory and Practice Nairobi: Nairobi University Process.

[9]. Oni, J (1997) The Administration of Nigeria Higher Education System. Abeokuta: Gbemi Sadipo Press Ltd.

[10]. Ukeje, B. O, Akabogu, G.C and A Ndu (1992) Educational Management, Theory and Practice Abuja: Totan Publishers Ltd.

[11]. Uyanga, R. E (1989) Educational Administration and Planning. A collaboration Approach, Lagos: Agege Press.

[12]. Washburn, J. M and J. M Hammand (1982) Students Leadership Camp for Improving School Climate Educational Leadership 39 (37) 